\title{
Investigation of Anti-proliferative and Anti-migratory Properties of Recombinant J2-C2 Against Tumor Cells
}

\section{Mustafa SONGUR ${ }^{1}$, Sema BİLGİN ${ }^{2}$, Seçil ERDEN TAYHAN ${ }^{1}$, İsa GÖKÇE ${ }^{1}$}

\begin{abstract}
Cancer is a big public health problem in many parts of the world. A novel anti-tumor protein (J2-C2) was previously isolated from Arca inflata and it was reported that this protein had antiproliferative effect on some human tumor cell lines such as A549, HepG2 and SPC-A-1. In this study, firstly, J2-C2 was produced by recombinant techniques in the Escherichia coli strain BL21 (DE3) pLysE and this protein was purified by Ni-NTA agarose affinity chromatography. Expressed recombinant J2C2 was analyzed with SDS-PAGE. $75.5 \mathrm{mg} \mathrm{ml}^{-1}$ of J2-C2 was achieved from a $600 \mathrm{~mL}$ culture. Then using HT-29, MCF7 and PC3 cancer cell lines, we showed the effect of recombinant of J2-C2 on cell proliferation, migration and apoptosis in a cell specific manner. Cell viability was measured using MTT assay. Additionally, real-time-qPCR was applied to analyze the transcript levels of apoptosis related genes such as Bcl-2, Bax and p53. The $2^{-\Delta \Delta \mathrm{Ct}}$ method was performed to determine the relative changes in gene transcription. Moreover, scratch wound healing assay was performed to evaluate the effect of J2-C2 on cancer cell migration. Consequently, we found that recombinant J2-C2 did not have a significant effect on cell viabilities of MCF7, PC3 and HT29 in concentration-dependent manner. Furthermore, our results showed that recombinant J2-C2 declined HT29, MCF7 cell migration. However, we did not observe the same results for PC3 cancer cell line.
\end{abstract}

Keywords: Recombinant J2-C2, therapeutic protein, cell proliferation, cell migration, apoptosis.

\footnotetext{
${ }^{1}$ Mustafa SONGUR (Orcid ID: 0000-0002-8581-9992), Seçil ERDEN TAYHAN (Orcid ID: 0000-0001-8473-5896), İsa GÖKÇE (Orcid ID: 0000-0002-5023-9947), Tokat Gaziosmanpaşa Üniversitesi, Mühendislik ve Mimarlık Fakültesi, Genetik ve Biyomühendislik Bölümü, Tokat, Türkiye/ Department of Genetics and Bioengineering, Faculty of Engineering and Architecture, Tokat Gaziosmanpaşa University, Tokat, Turkey

${ }^{2}$ Sema BILLGIN (Orcid ID: 0000-0001-5921-5437), Tokat Gaziosmanpaşa Üniversitesi, Fen Edebiyat Fakültesi, Kimya Bölümü, Tokat, Türkiye/ Department of Chemistry, Faculty of Art and Science, Tokat Gaziosmanpaşa University, Tokat, Turkey

*Sorumlu Yazar/Corresponding Author: Sema BİLGİN, e-mail: sema.bilgin@gop.edu.tr

$\mathrm{Bu}$ çalışma Mustafa Songur'un Lisans bitirme tezinden üretilmiştir.
}

Geliş tarihi / Received: 01-05-2020

Kabul tarihi / Accepted: 19-07-2020 


\section{INTRODUCTION}

Cancer is one of the biggest health problems in the world today. In addition, there are deficiencies in the category of antimetastatic drugs in chemotherapy. However, metastasis is one of the main causes of treatment failure and cancer-related deaths in cancer patients (Qian et al.,2017). Therefore, the development of possible therapeutic agents that can suppress metastasis is very important for cancer treatment (Li et. al., 2019).

Chemotherapy is one of the most effective methods for cancer treatment. Toxic side effects of chemotherapy and acquired chemotherapy resistance are still important problems to be solved (Cheok, 2012; Fan et. al., 2019).

Therapeutic proteins are a critical component of the pharmaceutical industry and are actively used in the treatment of many diseases, including cancer (Lagassé et. al., 2017). In the past, the main way to obtain a specific therapeutic protein was to isolate it from a natural source. Generally, this method was inefficient and time consuming. Recently, therapeutic proteins can be produced recombinantly with high efficiency with the developing recombinant DNA technology.

Recombinant therapeutic proteins are produced in different prokaryotic and eukaryotic systems such as mammalian, insect cells, bacteria and yeast. The majority of therapeutic proteins are produced in in mammalian cell lines because they have ability to produce high-quality proteins which are similar to the naturally occurring ones (Andersen et. al., 2002; Assenberg et. al., 2013). However, many recombinant therapeutic proteins are produced in Escherichia coli because of its inexpensive and fast high-density cultivation, the well-characterized genetics, and high-yield production (Swiech et. al., 2012; Rosano et. al., 2014).

In a previous research, a novel in vitro anti-tumor protein J2-C2 with a molecular weight of 27.153 kDa was purified from the Arca inflata (Zhu et. al., 2017). Arca inflata, a member of the family Arcidae which is a commercially important bivalve species in Asian countries (Li et. al., 2008). J2-C2 is a monomeric and a non-glycoprotein. As stated in the article published in 2017, Zhu and his friends investigated the anti-tumor property of J2-C2 against some human tumor cell lines (lung and liver) and also reported that the $\mathrm{IC}_{50}$ values of this isolated protein were $42.38,45.64$ and $48.73 \mu \mathrm{M}$ for $\mathrm{A} 549$ (lung), HepG2 (liver) and SPC-A-1(lung) cell lines, respectively.

In the current study, J2-C2 was first recombinantly produced to obtain a high purity and desired amount of protein for use in biological activity experiments. And then we tested the anticancer potential of recombinant J2-C2 in MCF7 (breast), HT29 (colon) and PC3 (prostate) cancer cell lines with MTT assay. Additionally, the effect of $\mathrm{J} 2-\mathrm{C} 2$ on cancer cell migration and Bcl-2, Bax, p53 gene expression were analyzed.

\section{MATERIALS AND METHODS}

\section{Gene Cloning and Expression}

Recombinant protein expression using bacterial and other eukaryotic host organisms is a fundamental technology for protein production. The basic step in recombinant protein expression is codon optimization where a coding sequence for a protein of interest is designed by synonymous substitution aiming to enhance its expression level. For example, a conventional approach is to substitute rare codons by frequent codons according to the genomic codon usage in a host organism (Saito et.al., 2019). In this context, we performed a codon optimization study for $J 2-C 2$ gene sequence from A.inflata (Zhu et. al., 2017) on the basis of Escherichia coli. The optimized synthetic gene was synthesized by Biomatik Corporation. Escherichia coli strain BL21 (DE3) pLysE (Novagen, Inc.) was used as the host 
for recombinant J2-C2 expression. This strain was transformed by Pet30a-J2-C2 plasmid. Transformed cells were spread on several Luria-Bertani (LB) agar plates containing both $50 \mu \mathrm{g} \mathrm{mL}^{-1}$ kanamycine and chloramphenicol $\left(34 \mu \mathrm{g} \mathrm{mL}^{-1}\right)$. One colony of BL21 (DE3) pLysE recombinant was cultivated in $4 \mathrm{~mL}$ of selective LB medium and was grown at $37^{\circ} \mathrm{C}$ with orbital shaking $(240 \mathrm{rpm})$ for $16 \mathrm{~h}$. This overnight culture was inoculated into $600 \mathrm{~mL}$ of selective $\mathrm{LB}$ and incubated at same conditions until the $\mathrm{OD}_{600}$ was 0.6. The expression of recombinant protein was induced by adding IPTG to a final concentration of $0.001 \mathrm{M}$.

\section{Purification of J2-C2}

Following additional three hours of incubation, the culture was harvested by centrifugation and the cell pellets were resuspended in $100 \mathrm{mM}$ Tris- $\mathrm{HCl}$ buffer ( $\mathrm{pH}$ 7.0) containing $1 \mathrm{mg} \mathrm{mL}^{-1}$ lysozyme, $1 \mathrm{mM}$ PMSF and $1 \mathrm{mM}$ benzamidine. The cells were lysed by a sonicator (Sonics VCX 130) and the insoluble fraction was collected by high speed centrifugation (Vision VS-30000i) at $30.000 \mathrm{rpm}, 4^{\circ} \mathrm{C}$ for $1 \mathrm{~h}$. Ni-NTA metal-affinity chromatographic procedure (Qiagen) was used to purification of recombinant protein carrying N-terminal 6x histidine (containing six histidine residues). Purity of recombinant J2-C2 was determined by $12 \%$ SDS-PAGE and visualized by commasie brillant blue (Weber et. al., 1972). The protein concentration was determined using UV spectroscopy by measuring the absorbance of the pure protein at $280 \mathrm{~nm}$ (Cabrita et. al., 2004). The purified proteins were collected and dialyzed against PBS (phosphate buffered saline). The dialyzed protein was stored $4^{\circ} \mathrm{C}$ until using for cancer cell proliferation and migration analyses.

\section{MTT Cell Viability Assay}

Antiproliferative effects of recombinant J2-C2 was investigated on cancer cell lines using 3-(4,5dimethylthiazol-2-yl)-2,5-diphenyltetrazolium bromide (MTT) (Serva, Germany) cell proliferation assay. This was performed according to the method described in our previous studies (Ispir et.al.,2019; Inan et al., 2018). HT-29, PC3 and MCF7 cancer cells were cultured in multiwell plates and in media (RPMI 1640 and DMEM, respectively) with 10\% FBS. These cell lines were treated with recombinant J2-C2 at eight different doses (240-1,875 $\mathrm{g} \mathrm{ml}^{-1}$ ) for 24 and 48 hours. 5-Fu (5-fluorouracil) was used as a positive control reagent.

\section{Cell Migration Assay}

Tumor cell migration was examined in vitro by scratch wound closure model. Tumor cells (HT29, PC3, MCF7) were seeded $\left(5 \times 10^{4}\right.$ cells well $\left.^{-1}\right)$ in 6 -well plates in appropriate culture media. When cells reached more than $80 \%$ confluency, cell monolayer was wounded by a steril $200-\mu 1$ pipette tip, the medium and cell debris were aspirated and all the wells were washed with sterile phosphate buffer saline. Then cells were treated with $240 \mu \mathrm{g} \mathrm{ml}^{-1}$ of J2-C 2 which was determined by MTT cell viability assay in the previous experimental stage. Images were captured with an inverted light microscope (OLYMPUS, Japan) at different time points (0h, 24h and 48h) post- J2-C2 administration. Percentage of cell migration rate was calculated with the following formula= (remaining wound area/ wound area at $0 \mathrm{~h}$ ) $\mathrm{x} 100$. These wound areas were measured by image analysis software of OLYMPUS inverted light microscope. The calculated values were compared with negative control and evaluated whether the substance was effective on cancer cell migration.

\section{RNA Extraction, cDNA Synthesis and Quantitative PCR Analysis}

For quantitative RT-PCR analysis of p53, Bax and Bcl-2 mRNA expression levels, confluent cancer cells (HT-29, PC3, MCF7) were treated with $240 \mu \mathrm{g} \mathrm{ml}^{-1}$ of compound for $48 \mathrm{~h}$. Controls were treated with the same amount of medium as used in the corresponding experiments. After the incubation 
period, total RNA was extracted from the cultured cell using TRIzol reagent (Ambion, USA) according to the manufacturer's protocol. RNA purity and concentration were assessed by spectrophotometry using the $260 \mathrm{~nm} / 280 \mathrm{~nm}$ ratio. Then cDNA was obtained using the manual which was described by the manufacturer of reverse transcriptase enzyme (Thermo Scientific, USA).

Real-time quantitative PCR (qRT-PCR) was conducted with qTOWER3G Real-Time PCR Thermocycler using EvaGreen. The primer pairs for genes were presented in Table 1. Glyceraldehyde3-phosphate dehydrogenase (GAPDH) was used as a housekeeping gene. All experiments were performed in triplicates. Target cDNA was amplified as follows: $3 \mathrm{~min}$ at $94^{\circ} \mathrm{C}$ then 40 cycles of amplification (denaturation at $94^{\circ} \mathrm{C}$ for $30 \mathrm{~s}$, annealing at $56^{\circ} \mathrm{C}$ for $30 \mathrm{~s}$ and elongation at $72^{\circ} \mathrm{C}$ for $1 \mathrm{~min}$ per cycle). The increase in fluorescence was measured and recorded in real-time during the elongation step. The $2^{-\Delta(\Delta C T)}$ method (Priego, et.al., 2008; Rao et. al., 2013) was used for relative quantitation of Bax, Bcl-2, p53 mRNA expression.

Table 1. Oligonükleotides utilized for qRT-PCR amplification

\begin{tabular}{ll}
\hline Gene & Primer Sequences \\
\hline P53 & 5'-GCCCAACAACACCAGCTCCT-3' \\
& 5'-CCTGGGCATCCTTGAGTTCC-3' \\
\hline Bcl-2 & 5'-ATCGCCCTGTGGATGACTGAG-3' \\
& 5'-CAGCCAGGAGAAATCAAACAGAGG-3' \\
\hline Bax & 5'-GGACGAACTGGACAGTAACATGG-3' \\
& 5'-GCAAAGTAGAAAAGGGCGACAAC-3' \\
GAPDH & 5'-GGATTTGGTCGTATTGGG-3' \\
& 5'-GGAAGATGGTGATGGGATT-3' \\
\hline
\end{tabular}

\section{Statistic Analysis}

Statistic analysis was performed using Student's t-test on all data. A statistically significant difference was considered with a $p$ value $<0.05$.

\section{RESULTS AND DISCUSSION}

\section{Gene Cloning and Expression}

Cell cultures were harvested $3 \mathrm{~h}$ after IPTG induction, sonicated, separated into soluble and insoluble fractions and recombinant J2-C2 was purified by Ni-NTA affinity chromatography as detailed in materials and methods. The molecular weight and molar absorption coefficient of recombinant protein were respectively calculated as 28631.43 Dalton and $38180 \mathrm{M}^{-1} \mathrm{~cm}^{-1}$ by using "ExPASy ProtParam tool". Subsequently the total yield of purified recombinant J2-C2 protein was determined as $75.5 \mathrm{mg} \mathrm{ml}^{-1}$ by measuring absorbance at $280 \mathrm{~nm}$ on UV spectrophotometer. The recombinant J2-C2 expression was confirmed by SDS-PAGE. The SDS-PAGE analysis showed that the purified protein around $28 \mathrm{kDa}$ which corresponds with a theoretical molecular weight of 28631.43 Da (Figure 1). 


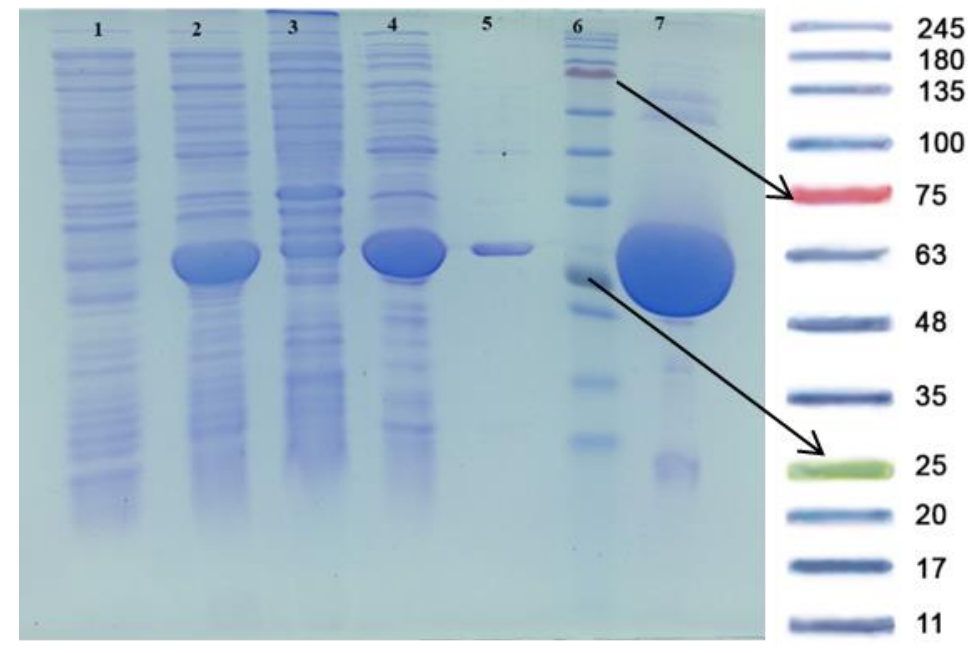

Figure 1. Purification of J2-C2 was confirmed with SDS-PAGE (\%12). 1. Bacterial cell lysates before IPTG addition, 2. Bacterial cell lysates after IPTG addition 3. Collected pellet after centrifugation of the lysate 4. Collected supernatant after centrifugation of the lysate, 5. Wash with $0.1 \mathrm{M}$ Tris-HCl buffer containing $10 \mathrm{mM}$ imidazole.,6.NZYColour Protein Marker II, 7. The eluate collected from Ni-NTA agarose affinity column.

\section{MTT Cell Viability Assay}

We performed MTT cell viability experiments and determined that the recombinant J2-C2 did not significantly affect cell viability and proliferation of MCF7, PC3 and HT29 (Figure 2).

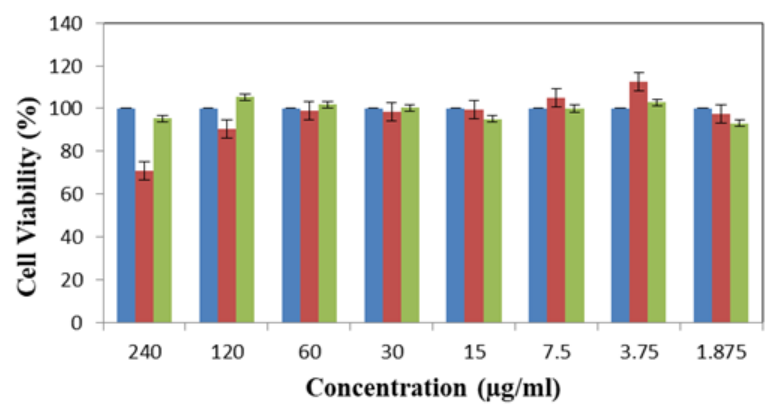

- Negative Control $=24 \mathrm{~h}=48 \mathrm{~h}$

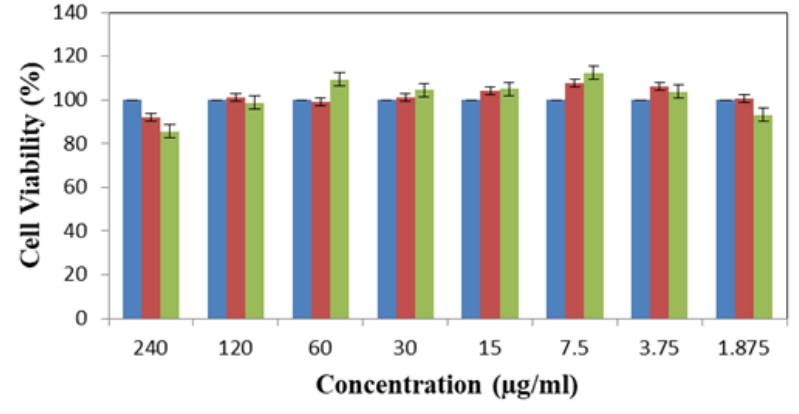

Negative Control $=24 \mathrm{~h} \quad \| 48 \mathrm{~h}$

A

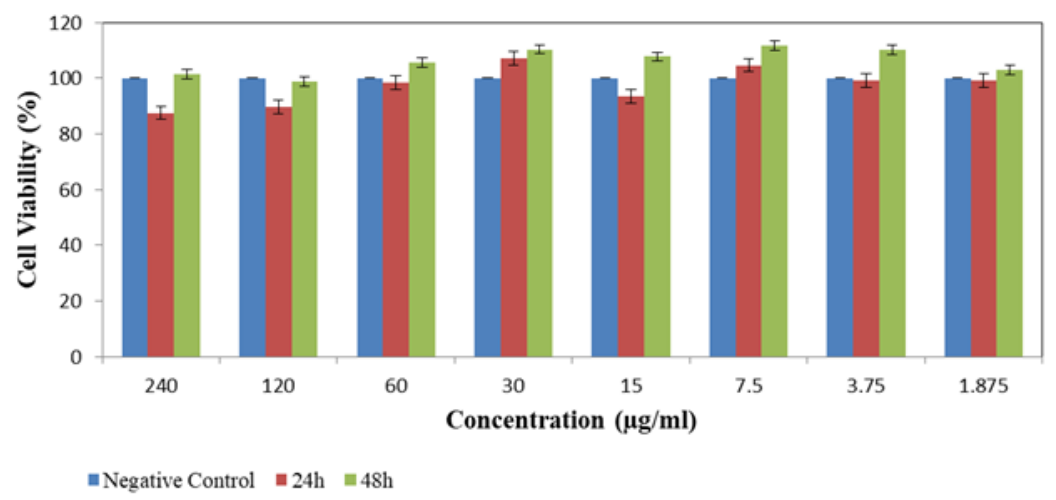

C

Figure2. The effect of different concentrations of J2-C2 on the viability of A. MCF7 cells B. PC3 cells C. HT29 cells 
In studies conducted by Jian Xu et al. (2013), it was reported that native J2-C2 isolated and purified from Arca inflata showed antiproliferative effect against A549, SPC-A-1 and HepG2 cell lines (Zhu et. al., 2017). However in our study recombinant J2-C2 didn't displayed remarkable anti-proliferation activity against HT29, MCF7 and PC3 cell lines.

\section{RNA Extraction, cDNA Synthesis and Quantitative PCR Analysis}

The effects of recombinant J2-C2 on mRNA expression of Bax, Bcl-2, p53 were shown in Fig. 3. The experiments were repeated three times. Results were normalized according to the the housekeeping gene (GAPDH) in the samples. Values represent the degree of changes in mRNA for recombinant J2C2 treated PC3, MCF7, HT29 relative to untreated ones.

Figure 3 shows the values of $2^{-\Delta \Delta C t}$ reflecting the fold change in $\mathrm{Bcl} 2, \mathrm{Bax}$ and p53 gene transcription level in cells treated with $240 \mu \mathrm{g} \mathrm{ml}{ }^{-1}$ recombinant $\mathrm{J} 2-\mathrm{C} 2$ for $48 \mathrm{~h}$, calculated relative to the level of GAPDH expression and the $\Delta \Delta \mathrm{Ct}$ value ranges. The value of $2^{-\Delta \Delta \mathrm{Ct}}>1$ reflects increased expression of the target gene, the value of $2^{-\Delta \Delta \mathrm{Ct}}<1$ points to a decrease in the gene expression.

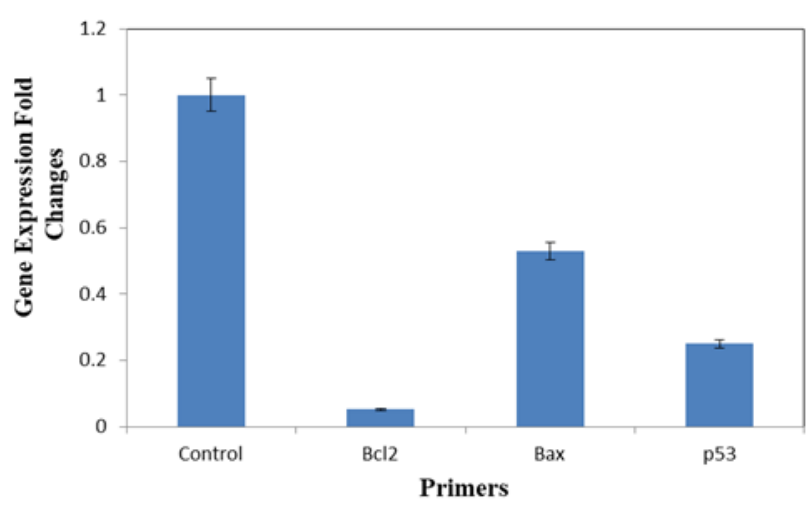

A

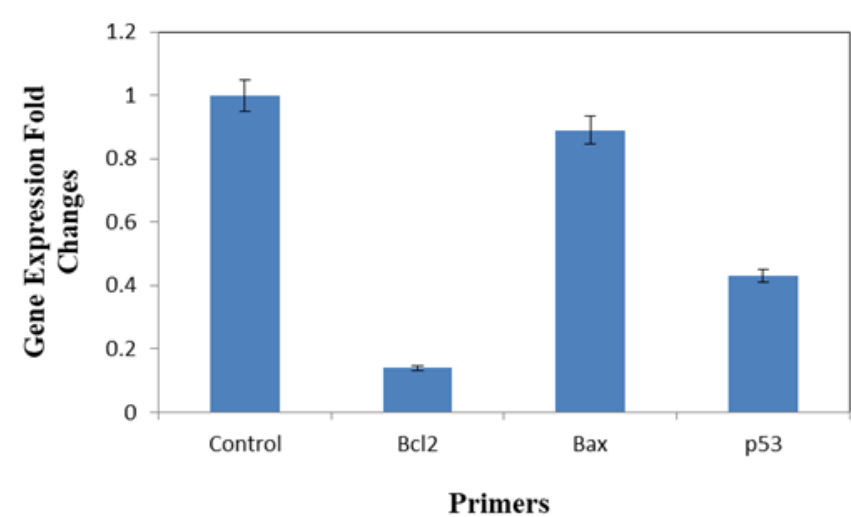

B

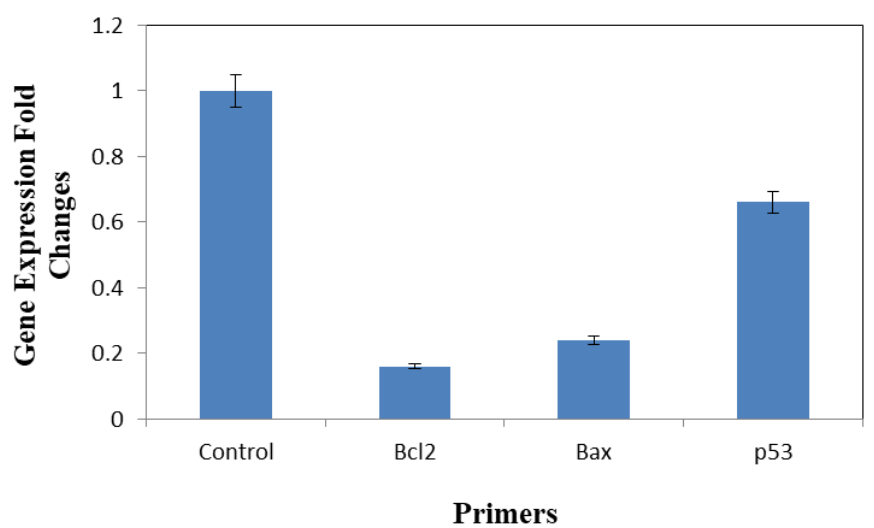

C

Figure 3. J2-C2 effect on mRNA levels of PC3 (A), MCF7 (B) and HT29 (C) cell lines

In all cell cultures treated with $240 \mu \mathrm{g} \mathrm{ml}^{-1}$ recombinant $\mathrm{J} 2-\mathrm{C} 2$ for $48 \mathrm{~h}, \mathrm{Bcl} 2$, Bax and p53 gene transcription tended to decrease below the transcription of these genes in the non-treated control cells (Table 2). There was no significant decrease in Bcl2 / Bax ratio in PC3, MCF7 and HT29 cell lines treated with $240 \mu \mathrm{g} \mathrm{ml}^{-1}$ recombinant J2-C2 for 48 hours. These results are compatible with the results of the cell viability assay $(p<0.005)$. 
Investigation of Anti-proliferative and Anti-migratory Properties of Recombinant J2-C2 Against Tumor Cells

Table 2. Down regulated genes in treated compared with untreated cell lines

\begin{tabular}{llllll}
\hline Symbol & Description & Gene name & \multicolumn{3}{c}{ Fold change (log 10 down regulation) } \\
& & & PC3 & MCF7 & HT29 \\
\hline Bcl2 & Anti-apoptosis & B-cell CLL/lymphoma 2 & -1.28 & -0.85 & -0.80 \\
Bax & Induction of apoptosis & Bcl2-associated X protein & -0.27 & -0.051 & -0.62 \\
p53 & Tumor suppressor gene & Tumor protein p53 & -0.60 & -0.37 & -0.18 \\
\hline
\end{tabular}

\section{Cell Migration Assessment}

To explore whether J2-C2 could inhibit breast, prostate, colon cancer cell migration, we carried out in vitro scratch assay which is used conveniently by cell scientists. Representative images and quantitative analysis are demonstrated in Figure 4 and 5.

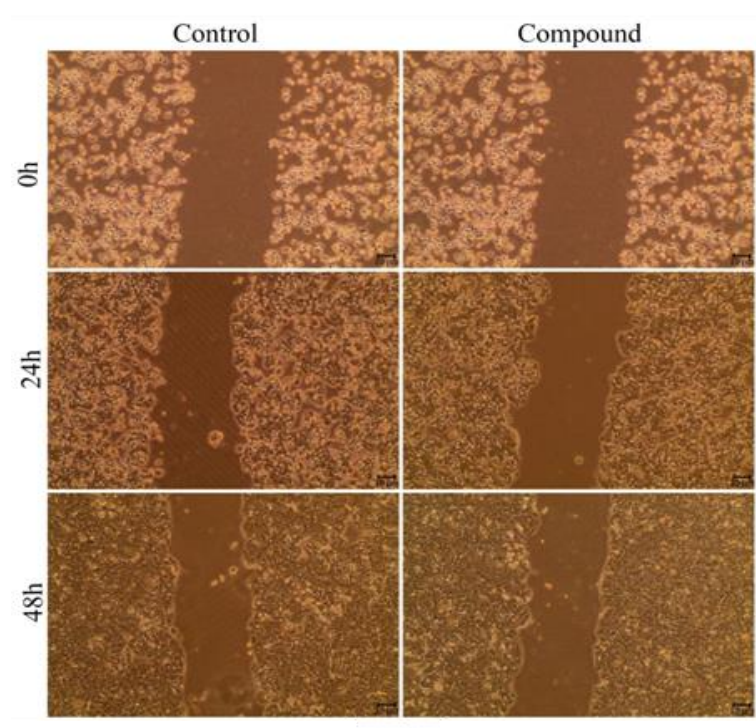

A

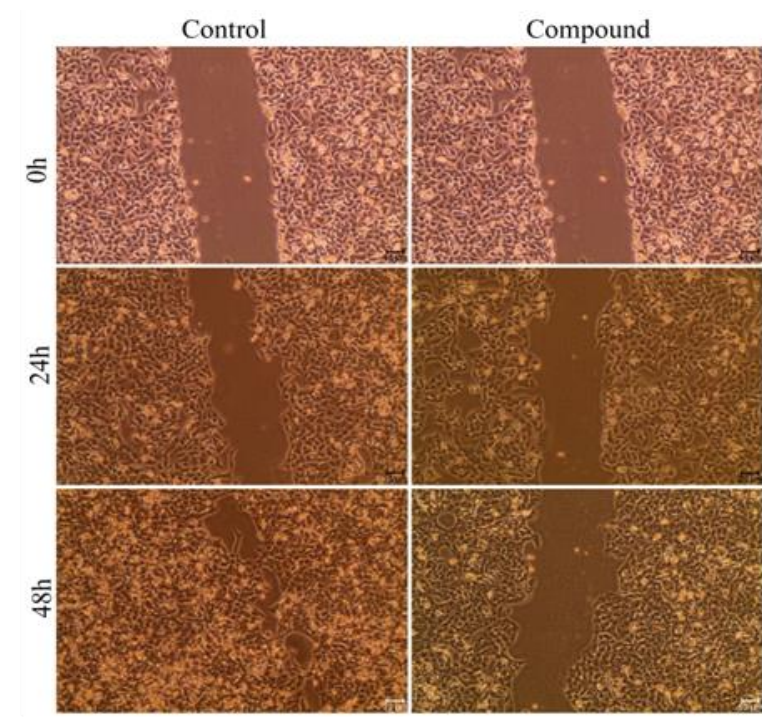

B

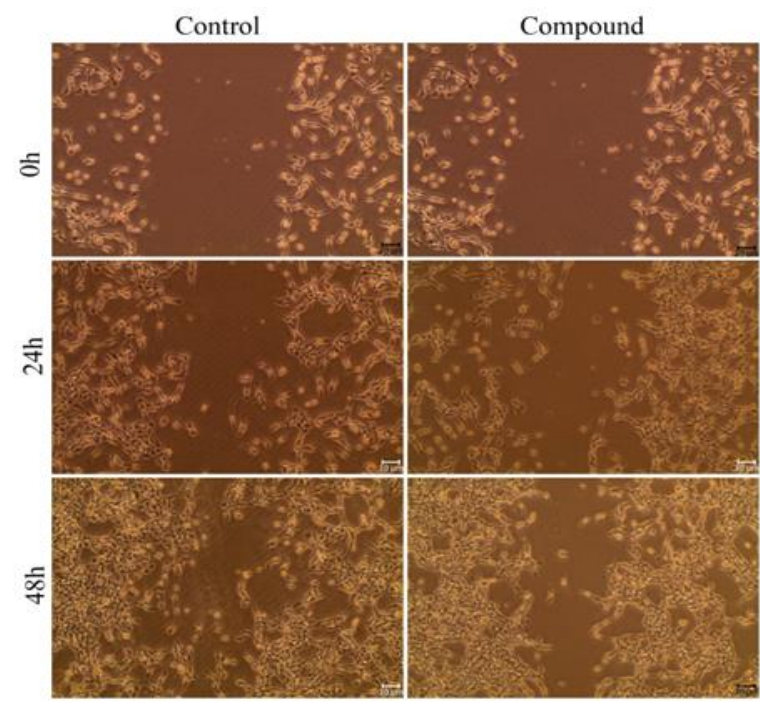

C

Figure 4. Efect of J2-C2 on migration of cancer cells in wound healing assay. The wounded monolayers which were created by scratching (A. HT29, B. MCF7, C. PC3) incubated for 24h and 48h alone (control) and in the precence of J2-C2 $(240 \mu \mathrm{g} / \mathrm{ml})$. The scale bars indicated $100 \mu \mathrm{m}$ for $\mathrm{x} 4$ magnification 


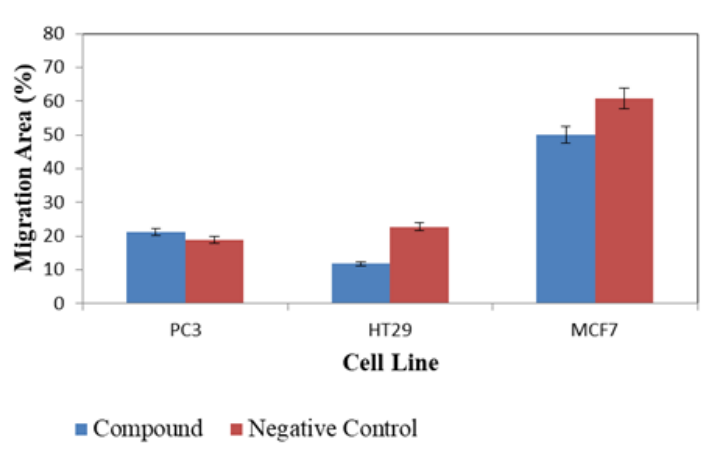

A

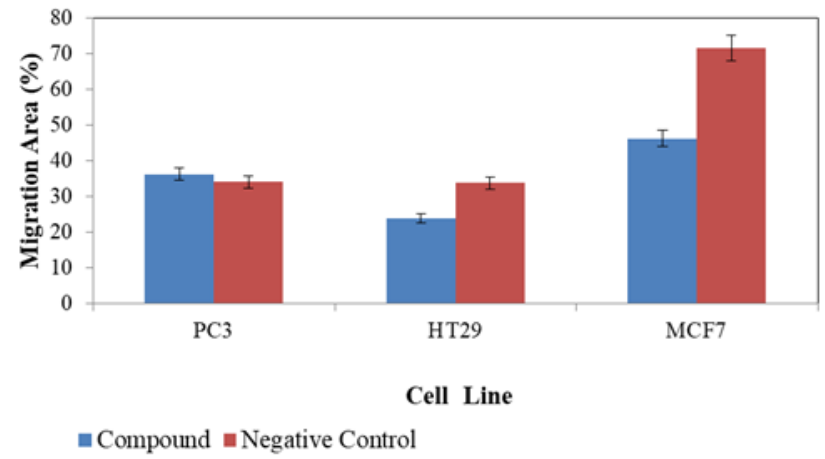

B

Figure 5. Effect of J2-C2 on migration of PC3, MCF7, HT29 cancer cells. Wound healing assay showing inhibiton of cell migration after $24 \mathrm{~h}(\mathrm{~A})$ and $48 \mathrm{~h}(\mathrm{~B})$ of exposure to $\mathrm{J} 2-\mathrm{C} 2\left(240 \mu \mathrm{g} \mathrm{ml}^{-1}\right)$

According to data that we obtained from wound-healing assay and MTT cell viability assay, we observed that J2-C2 protein reppressed cell migration of HT29 and MCF7 cells.

We did not find any significant direct effect of recombinant J2-C2 on PC3 cancer migration. However, this protein significantly inhibited the migration of HT29 and MCF7 cell lines. As a result, recombinant J2-C2 was more effective in blocking cell migration than cell viability inhibition.

Cancer metastasis, rather than primary tumors, is reported to account for over $90 \%$ of all cancer deaths, including colon, prostate and breast (Yang et. al., 2017; Ortega et. al.,2003). Research has shown that most colon cancer patients with cancer metastasis have low survival rates (Zhu et. al.,2016). Various chemotherapy drugs are used in clinical practice to inhibit colon cancer metastasis. Nevertheless, specific antimetastatic drugs are not sufficient for the treatment of solid cancer. Therefore, considering the importance of metastasis in cancer treatment and the need of oncologists for antimetastatic drugs, researches to develop drug candidates to prevent metastasis appear to be very valuable. The results show that recombinant $\mathrm{J} 2-\mathrm{C} 2$ can be considered as a drug candidate in this regard.

\section{CONCLUSION}

The anti-migrative effect of recombinant J2-C2 on PC3, MCF7 and HT29 were determined by investigating viability and migration of these cells treated with recombinant protein. The results demonstrated that recombinant J2-C2 inhibited migration of MCF7 and HT29 cancer cells. The effects of J2-C2 inhibition on migration were not a result of reduced viability. Because, MTT assay indicated that this recombinant protein did not demonstrate any anti-proliferative effects on these cells. In conclusion, our findings regarding the inhibitory effects of J2-C2 on cell migration suggest that recombinant J2-C2 may be useful as a therapy agent against breast and colon cancers.

\section{ACKNOWLEDGEMENTS}

Mustafa Songur was supported by TUBİTAK-BIDEB 2209B National Scholarship Program for Bachelor's degree students.

\section{REFERENCES}

Andersen DC, Krummen L, 2002. Recombinant protein expression for therapeutic applications. Current Opinion in Biotechnology. 13 (2), 117-123.

Assenberg R, Wan PT, Geisse S, Mayr, LM, 2013. Advances in recombinant protein expression for use in pharmaceutical research. Current Opinion in Structural Biology, 23 (3), 393-402.

Cabrita LD, Chow MKM, Bottomley SP, 2004. A Practical Guide To Protein Expression and Refolding From Inclusion Bodies. Biotechnolgy Annual Review, 10, 31-50. 
Cheok C F, 2012. Protecting normal cells from the cytotoxicity of chemotherapy. Cell Cycle 11 (12) 2227-2232.

Fan M, Wen Y, Ye D, Jin Z, Zhao P, Chen D, Lu X, He Q, 2019. Acid-Responsive $\mathrm{H}_{2}$-Releasing 2D MgB Nanosheet for Therapeutic Synergy and Side Effect Attenuation of Gastric Cancer Chemotherapy. Advanced Healthcare Materials. 8 (13).

Qian CN, Mei Y, Zhang J, 2017. Cancer metastasis: issues and challenges. Chinese Journal of Cancer, 36(38).

Ispir E, İkiz M, İnan A, Sünbül, AB, Erden Tayhan S, Bilgin S, Elmastaş M, 2019. Synthesis, structural characterization, electrochemical, photoluminescence, antiproliferative and antioxidant properties of $\mathrm{Co}(\mathrm{II}), \mathrm{Cu}(\mathrm{II})$ and $\mathrm{Zn}$ (II) complexes bearing the azo-azomethine ligands. Journal of Molecular Structure, 1182, 63-71 (2019).

Inan A, Sünbül AB, İkiz B, Erden Tayhan S, Bilgin S, Elmastaş M, Sayın K, Ceyhan G, Köse M, İspir E, 2018. Half-sandwich Ruthenium(II) arene complexes bearing the azo-azomethine ligands: Electrochemical, computational, antiproliferative and antioxidant properties. Journal of Organometallic Chemistry, 870, 7689.

Li H, Su J, Jiang J, Li Y, Gan Z, Ding Y, Li Y, Liu J, Wang S, Ke Y, 2019. Characterization of polysaccharide from Scutellaria barbata and its antagonistic effect on the migration and invasion of HT-29 colorectal cancer cells induced by TGF- $\beta 1$. International Journal of Biological Macromolecules, 131, 886-895.

Li J J, Li Q, 2008. Isolation and characterization of twelve novel microsatellite loci in the ark shell Scapharca broughtonii.Conserv. Genet., 9, 1055-1057.

Ortega A, 2003. A new role for GABA: inhibition of tumor cell migration. Trends in Pharmacological Sciences, 24 (4), 151-154.

Priego S, Feddi F, Ferrer P, Mena S, Benlloch M, Ortega A, Carretero J, Obrador E,Asensi M,and Estrela JM, 2008. Natural polyphenols facilitate elimination of HT-29 colorectalcancer xenografts by chemoradiotherapy: a Bcl-2- and superoxide dismutase 2-dependent mechanism. Molecular Cancer Therapeutics, 7(10).

Rao X, Huang X, Zhou Z, Lin X, 2013. An improvement of the $2^{\wedge}$ (-delta delta CT) method for quantitative realtime polymerase chain reaction data analysis. Biostat Bioinforma Biomath. 3(3), 71-85.

Rosano GL, Ceccarelli EA, 2014. Recombinant protein expression in Escherichia coli: Advances and challenges. Frontier in Microbiology, 5, 1-17.

Saito Y, Kitagawa W, Kumaga T, Tajima N, Nishimiya Y, Tamano K, Yasutake Y, Tamura T, Kameda T, 2019. Developing a codon optimization method for improved expression of recombinant proteins in actinobacteria scientific reports. Scientific Reports. 9:8338.

Swiech K, Picanço-Castro V, Covas T, Covas DT, 2012. Human cells: New platform for recombinant therapeutic protein production. Protein Expression and Purification. 84, 147-153.

Weber K, Pringle J, Osborn M, 1972. Measurement of molecular weights by electrophoresis on SDS-acrylamide gel. Methods in Enzymology, 26, 3-27.

Xu J, Chen Z, Song L, Chen L, Zhu J, Lv S, Yu R, 2013. A New in Vitro Anti-Tumor Polypeptide Isolated from Arca inflata. Marine Drugs, 11 (12), 4773.

Zhu P, Zhao N, Sheng D, Hou J, Hao C, Yang X, Zhu B, Zhang S, Han Z, Wei L, Zhang L, 2016. Inhibition of Growth and Metastasis of Colon Cancer by Delivering 5-Fluorouracil-loaded Pluronic P85 Copolymer Micelles. Scientific Reports, 6, 1-11.

Zhu J, Xu J, Wang Y, Li C, Chen Z, Song L, Gao J, Yu R, 2017. Purification and structural characterization of anti-tumor protein from Arca inflata. International Journal of Biological Macromolecules. 105, 103-110. 